\title{
There really is no such thing as mild diabetes: a new perspective on an old idea
}

\author{
MIKE BAXTER, RICHARD HUDSON
}

Although diabetes-related microvascular complications are the commonest cause of blindness, non-traumatic lower limb amputation and renal failure in the Western world, ${ }^{1}$ macrovascular disease outcomes dominate discussions on type 2 diabetes. Evidence that glycaemic interventions reduce mortality from cardiovascular disease is disappointing. ${ }^{2-4}$ Studies where beneficial effects on cardiovascular outcomes have been reported focus on non-glycaemic effects in very specific patient groups..$^{5-7}$

It is argued that the benefits of glycaemic control are small, and guidelines stress an 'individualised' approach to $\mathrm{HbA}_{1 \mathrm{c}}$ which, in reality, sanctions acceptance of increased $\mathrm{HbA}_{1 c}$ values.

This has overwhelmed a previous philosophy 'that there is no such thing as mild diabetes', and ignores the relationship between the incidence and impact of microvascular diabetic complications and glycaemic control.2,8

Gray et $a /,{ }^{9}$ using the UKPDS dataset, showed the potential benefits in microvascular complications of improved glycaemic control in newly diagnosed patients with type 2 diabetes. Eastman et a/10 described the potential microvascular benefits of achieving near 'normoglycaemia' control ( $\mathrm{HbA}_{1 \mathrm{c}} 55.2 \mathrm{mmol} / \mathrm{mol}$ (7.2\%)) in a population of patients with type 2 diabetes. This modelling study predicted that, if the whole population achieved an $\mathrm{HbA}_{1 \mathrm{c}}$ of $7.2 \%$ $(55.2 \mathrm{mmol} / \mathrm{mol})$ there would be a $72 \%$ reduction in diabetesrelated blindness, $87 \%$ reduction in end stage renal failure and a $67 \%$ reduction in amputations.

The Core Diabetes Model ${ }^{11,12}$ has examined the effect of $\mathrm{HbA}_{1 \mathrm{C}}$ targets on the incidence and cost of complications in the USA ${ }^{13,14}$ and the UK. Baxter et $a /{ }^{15}$ reported the impact of a modest sustained improvement in $\mathrm{HbA}_{1 \mathrm{c}}$ of $\sim 9 \mathrm{mmol} / \mathrm{mol}(0.8 \%)$ in all patients with type 2 diabetes in the UK over 25 years. This modest improvement would prevent 750,000 diabetic microvascular complications and estimated cost avoidance in excess of $£ 4.5$ billion.

This study has modelled a population-based incremental improvement in $\mathrm{HbA} 1 \mathrm{c}$ and has not adopted a prespecified target $\mathrm{HbA}_{1 \mathrm{c}}$ or targeted 'high-risk patients. Since 2002 a HbA $1 \mathrm{c}$ target strategy has been in place. This focuses on people with $\mathrm{HbA}_{1 \mathrm{c}}$

Sanofi, Guildford, UK

Address for correspondence: Dr Mike Baxter Medical Therapy Expert (Diabetes), Sanofi, One Onslow Street, Guildford, GU1 4YS, UK

Tel: +44 (0)1483 554068

E-mail:mike.baxter@sanofi.com

Br J Diabetes 2017; 17:24-25

http://dx.doi.org/10.15277/bjd.2017.113 above target who are thought of as 'high-risk'. ${ }^{16,17}$ These targets have been adjusted a number of times based on arguments about scientific validity and real-world achievability. ${ }^{18-21}$ Although targets are an accepted strategic device for improving performance, ${ }^{22}$ it is also recognised that they can unwittingly create a situation of binary outcome - success and failure - and be perversely counterproductive. ${ }^{23-25}$

A study using the CPRD primary care database ${ }^{26}$ showed that $70 \%$ of patients with type 2 diabetes where on one oral agent, $33 \%$ on two and only $7 \%$ on triple therapy. The mean $\mathrm{HbA}_{1 \mathrm{c}}$ in these groups was $68.3 \mathrm{mmol} / \mathrm{mol}(8.4 \%), 72.7 \mathrm{mmol} / \mathrm{mol}(8.8 \%)$ and $75 \mathrm{mmol} / \mathrm{mol}(9 \%)$, respectively. This generated the idea of 'clinical inertia', which describes the reluctance of clinicians to escalate therapy in the face of suboptimal diabetes control.

However, CSD data on the distribution of $\mathrm{HbA}_{1 \mathrm{c}}$ in the type 2 diabetes population give an alternative perspective to the issue of clinical inertia. ${ }^{27}$ The data show that the majority of people with type 2 diabetes (59\%) have an $\mathrm{HbA}_{1 \mathrm{c}}$ of $59 \mathrm{mmol} / \mathrm{mol}(7.5 \%)$ or below, 30\% an $\mathrm{HbA}_{1 \mathrm{c}}$ above $64 \mathrm{mmol} / \mathrm{mol}(8 \%)$ and only $16 \%$ above $75 \mathrm{mmol} / \mathrm{mol}$ (9\%).

These data highlight two important issues:

- An alternative explanation of why inertia is apparently common but may be unrecognised in primary care.

- That there is also a phenomenon of 'understandable/acceptable' clinical inertia based on $\mathrm{HbA}_{1 c}$ targets, and this is potentially much more damaging than we had previously thought.

Clinical inertia suggests a wilful inactivity on behalf of the healthcare professional who fails to escalate therapy when required. However, these data show that a large proportion of the type 2 diabetes population (59\%) who would be seen in primary care actually have an $\mathrm{HbA}_{1 \mathrm{c}}$ which would be considered at target $(<59 \mathrm{mmol} / \mathrm{mol}$ $(7.5 \%))$. These patients would currently not be viewed as requiring additional therapy. Current clinical inertia in the real world may therefore be a reflection of the fact that a majority of patients with type 2 diabetes, when judged against accepted $\mathrm{HbA}_{1 \mathrm{c}}$ targets, do not appear to need therapy intensification.

However, Baxter et al also reported that, although the greatest reduction in costs per patient achieved by improving glycaemic control was seen, as predicted, in those people with the highest $\mathrm{HbA}_{1 \mathrm{c}}$ (individual benefit), 9,10,28 this high-risk group accounts for less than $30 \%$ of the total population and only accounts for $50 \%$ of the cost avoidance seen in the whole population.

The other $50 \%$ of cost aviodance is actually achieved by reducing (or preventing the rise in) $\mathrm{HbA}_{1 \mathrm{c}}$ in people with $\mathrm{HbA}_{1 \mathrm{c}}$ values below $59 \mathrm{mmol} / \mathrm{mol}$ (7.5\%). This group actually accounts for the majority (59\%) of the type 2 diabetes population and would cur- 
rently be considered at target 'low risk and safe'. ${ }^{15}$

This low-risk at or near target population has become 'hidden in plain sight' and the significant contribution to the overall population risk and cost completely overlooked.

The clinical inertia attributed to inaction in people we currently recognise as high-risk may be magnified by the failure to recognise that the majority of patients with type 2 diabetes have $\mathrm{HbA}_{1 \mathrm{c}}$ at or below current targets and, although at low individual risk, make a significant contribution to the total population risk (and costs).

We should consider a strategy based on incremental improvement in $\mathrm{HbA}_{1 \mathrm{c}}$ in all patients with type 2 diabetes by (1) recognising the reality of continuous risk; (2) moving away from dividing the population into those who have failed (and are at risk) and those who succeed and are thought of as 'safe'; and (3) focusing on the 'prevention of progression' and ensuring microvascular risk is recognised and appropriately managed through glycaemic control, as it is clear that there really is no such thing as mild diabetes.

Conflict of interest $\mathrm{RH}$ and MB are employed by Sanofi. The Impact Diabetes programme has been developed in partnership with Diabetes UK, JDRF and Sanofi Diabetes and is funded by Sanofi.

\section{References}

1. Textbook of diabetes. Blackwell Scientific Publications, 1991.

2. UK Prospective Diabetes Study (UKPDS) Group. Intensive blood-glucose control with sulphonylureas or insulin compared with conventional treatment and risk of complications in patients with type 2 diabetes (UKPDS 33). Lancet 1998:352:837-53. https://doi.org/10.1016/S0140-6736(98)07019-6

3. Gaede P, Vedel P, Larsen N, Jensen GV, Parving HH, Pedersen O. Multifactorial intervention and cardiovascular disease in patients with type 2 diabetes. N Engl J Med 2003;348:383-93.

https://doi.org/10.1056/NEJMoa021778

4. Gerstein HC, Miller ME, Genuth $\mathrm{S}$, et al. Long-term effects of intensive glucose lowering on cardiovascular outcomes. N Engl J Med 2011; 364:818-28. http://dx. doi.org/10.1056/NEJMoa1006524

5. UK Prospective Diabetes Study (UKPDS) Group. Effect of intensive bloodglucose control with metformin on complications in overweight patients with type 2 diabetes (UKPDS 34). Lancet 1998;352:854-65. https://doi.org/10.1016/S0140-6736(98)07037-8

6. Zinman B, Wanner C, Lachin JM, et al. Empagliflozin, cardiovascular outcomes, and mortality in type 2 diabetes. N Engl J Med 2015;373:2117-28. http://dx.doi.org/10.1056/NEJMoa1504720

7. Marso SP, Daniels GH, Brown-Frandsen $\mathrm{K}$, et al. Liraglutide and cardiovascular outcomes in type 2 diabetes. N Engl J Med 2016;375:311-22. http://dx.doi.org/10.1056/NEJMoa1603827

8. Hex N, Bartlett C, Wright D, Taylor M, Varley D. Estimating the current and future costs of type 1 and type 2 diabetes in the UK, including direct health costs and indirect societal and productivity costs. Diabet Med 2012;29:85562. http://dx.doi.org/10.1111/j.1464-5491.2012.03698.x

9. Gray A, Raikou M, McGuire A, et al. Cost effectiveness of an intensive blood glucose control policy in patients with type 2 diabetes: economic analysis alongside randomised controlled trial (UKPDS 41). United Kingdom Prospective Diabetes Study Group. BMJ 2000;320:1373-8. https://doi.org/10.1136/bmj.320.7246.1373

10. Eastman RC, Javitt JC, Herman WH, et al. Model of complications of NIDDM. II. Analysis of the health benefits and cost-effectiveness of treating NIDDM with the goal of normoglycemia. Diabetes Care 1997;20:735-44. https://doi.org/10.2337/diacare.20.5.735

11. McEwan P, Foos V, Palmer JL, Lamotte M, Lloyd A, Grant D. Validation of the IMS CORE Diabetes Model. Value Health 2014;17:714-24. https://doi.org/10.1016/j.jval.2014.07.007

12. Hornberger J. Computer modeling of diabetes and its complications: a report on the Fifth Mount Hood Challenge Meeting. Value Health 2013;16:453-4. https://doi.org/10.1016/j.jval.2013.04.003

13. Palmer AJ, Roze S, Valentine WJ, et al. Impact of changes in HbA1c, lipids and blood pressure on long-term outcomes in type 2 diabetes patients: an analysis using the CORE Diabetes Model. Curr Med Res Opin 2004; 20(Suppl 1):S53-S58. https://doi.org/10.1185/030079903125002611

14. Valentine WJ, Palmer AJ, Nicklasson L, Cobden D, Roze S. Improving life expectancy and decreasing the incidence of complications associated with type 2 diabetes: a modelling study of HbA1c targets. Int I Clin Pract 2006;60:1138-45. https://doi.org/10.1111/j.1742-1241.2006.01102.x

15. Baxter M, Hudson R, Mahon J, et al. Estimating the impact of better management of glycaemic control in adults with type 1 and type 2 diabetes on the number of clinical complications, and the associated financial benefit. Diabet Med 2016;33:1575-81. http://dx.doi.org/10.1111/dme.13062.

16. Mencken HL. A Mencken Chrestomathy. 1949.

17. Department of Health. National Service Framework for diabetes: delivery strategy. 2002 (accessed 18 March 2016).

18. Stratton IM, Adler Al, Neil HA, et al. Association of glycaemia with macrovascular and microvascular complications of type 2 diabetes (UKPDS 35): prospective observational study. BMJ 2000;321:405-12. https://doi.org/10.1136/bmj.321.7258.405

19. National Audit Office. The management of adult diabetes services in the NHS. 2012 (accessed 18 March 2016).

20. National Audit Office. The management of adult diabetes services in the NHS: progress review. 2015 (accessed 18 March 2016).

21. Diabetes UK. State of the Nation 2016 (accessed 19 July 2016).

22. Ambrose ML, Kulik C. Old friends, new faces: motivation research in the 1990s. J Management 1999;25:231-92. https://doi.org/10.1177/014920639902500302

23. Lopes LL. Between hope and fear: the psychology of risk. Advan Exp Social Psychol 1987;20:255-95. https://doi.org/10.1016/S0065-2601(08)60416-5

24. Deming E. Out of the crisis. MIT Technology Centre for Advanced Engineering Study, Cambridge, MA, 1990.

25. Gregory AJ. Target setting, lean systems and viable systems: a systems perspective on control and performance measurement. J Operational Res Soc 2007;58:1503-17. http://dx.doi.org/10.1057/palgrave.jors.2602319

26. Khunti K, Anderson M, Wolden ML, Davies ML, Thorsted BL. Clinical inertia in people with type 2 diabetes. A retrospective cohort study of more than 80,000 people. Diabetes Care 2013;36:3411-17. http://dx.doi.org/10.2337/dc13-0331

27. CSD Patient Data CSDUL. Derived from the CSD database. 2014.

28. Vijan S, Hofer TP, Hayward RA. Estimated benefits of glycemic control in microvascular complications in type 2 diabetes. Ann Intern Med 1997; 127:788-95 https://doi.org/10.7326/0003-4819-127-9-199711010-00003

29. Basu S, Yudkin JS, Sussman JB, Millett C, Hayward RA. Alternative strategies to achieve cardiovascular mortality goals in China and India: a microsimulation of target- versus risk-based blood pressure treatment. Circulation 2016;133:840-8. http://dx.doi.org/10.1161/CIRCULATIONAHA.115.01998 